\title{
PRONATOR QUADRATUS MUSCLE PEDICLED BONE GRAFT FOR DELAYED UNION SCAPHOID
}

\author{
By
Khaled Ahmed Abo Al-Fadl, Ibrahim Ahmed Hussein and Faisal Hassan Zayed \\ Department of Orthopedics, Faculty of Medicine, Al-Azhar University \\ E-mail: ibnelwalid85@gmail.com
}

\begin{abstract}
Background: The human scaphoid bone is one of the carpal bones of the wrist. Its fracture is the most common type of carpal bone fracture. Scaphoid nonunion is a well-known and common problem. Both clinical and biological factors contribute to the development of nonunion. Several techniques of bone grafting have been used in the management of scaphoid fracture nonunion. The union rate achieved with standard nonvascularized bone grafts was poor, especially in case of avascular necrosis and pseudarthroses, whereas the use of vascularized bone grafts results in better union rates. Pronator quadratus pedicled bone graft is described as one of the successful techniques that treat delayed union of the scaphoid fracture.
\end{abstract}

Objective: To evaluate the outcomes and results of pronator quadratus muscle pedicle bone graft for patients who were suffering from delayed union or nonunion of scaphoid bone fracture.

Patients and Methods: Ten patients suffering from delayed and non-united scaphoid fractures, seven males and three females, aging from 17 to 54 years old. We used the pronator quadratus muscle pedicled bone graft to treat all these patients.

Results: Complete union was achieved in seven patients, 6 patients of them were suffering from waist non united scaphoid fracture, and one patient of four patients suffering from non-united proximal pole scaphoid fracture.

Conclusion: The use of the pronator quadratus pedicled bone graft in delayed union of the scaphoid waist fractures achieved a high rate of union with excellent and good functional outcomes. A poor result occurred on using the pronator quadratus pedicled bone graft in delayed union of the scaphoid proximal pole fracture.

Keywords: Scaphoid fracture - nonunion - pronator quadratus pedicled graft - internal fixation.

\section{INTRODUCTION}

The scaphoid is the most common carpal to fracture with an estimated incidence is 4.3 per 10,000 people. Misdiagnosis and improper treatment can result in potentially devastating complications such as delayed union, avascular necrosis, and instability and ultimately osteoarthritis (Nassiri, 2016).

People with scaphoid fractures generally have snuff box tenderness. Focal tenderness is usually present in one of three places: 1) volar prominence at the distal wrist for distal pole fractures; 2) anatomic snuff box for waist or midbody fractures and 3) distal to Lister's tubercle for proximal pole fractures (Yin, 2010).

Scaphoid nonunion is a well-known and common problem in trauma and hand surgery. Nonunion occurs in $10 \%$ to $15 \%$ of patients if a scaphoid fracture is not detected and treated. Nonunion of 
proximal pole fractures can range of up to 30\% (Werdin, 2014).

Both clinical and biological factors contribute to the development of nonunion. Biological factors include the degree of fracture displacement, the fragile vascular supply of the scaphoid, and its complex anatomy. Clinical factors include variable patient symptoms such as minimal pain and swelling, compliance with immobilization, lack of medical and radiological diagnosis, and delays in treatment (Wong and von Schroeder, 2011).

When a massive free bone graft must be incorporated into a large bone defect in the presence of a poor vascular recipient bed, the risks of absorption and failure of the graft to revascularize are high. Studies have confirmed that a bone graft that is transferred to a recipient site with an intact pedicle of blood supply remains viable. In addition, it unites directly with the recipient bone without necessity of revascularization or replacement by creeping substitution. It also provides a live bone bridge for reconstruction of a massive bone defect and is a ready source of vascular osteogenic tissue, which sprouts new outgrowths to revascularize avascular recipient bone tissue (Rashed, 2015).

The usage of a pronator quadratus pedicled vascularized bone graft of the distal radius to revascularize the nonunited scaphoid fractures was described as one of the most successful, less complex, and quite elegant procedures (Lee et al, 2015).

The aim of this study was to evaluate the outcomes and results of pronator quadratus muscle pedicle bone graft for patients who are suffering from delayed union or nonunion of scaphoid bone fracture.

\section{PATIENTS AND METHODS}

This was a prospective study involving 10 patients with delayed or non-united scaphoid fractures underwent at the orthopedic outpatient clinic of Al-Azhar University Hospitals and Ain Shams General Hospital between the period of October 2017 till March 2020. Patients were checked with X-rays, clinical evaluation, and functional assessment.

\section{Inclusion criteria:}

Patients with delayed or non-united scaphoid fracture for more than 3 months of primary intervention, with or without avascular necrosis, without severe arthritis, bone resorption and marked carpal instability, and not suffering any general comorbidities or neurological disease affecting the diseased wrist.

\section{Exclusion criteria:}

Patients with acute scaphoid fracture, or those who developed severe arthritis, bone resorption and marked carpal instability and those who were suffering any general comorbidities or neurological disease affecting the diseased wrist.

After approval by hospital ethics committee, informed consents were obtained from all the patients.

Preoperative and postoperative clinical and radiographic evaluation was carried out. Clinical evaluation involved assessment of pain, range of motion of the wrist, and grip strength. The range of motion was measured with a goniometer, including flexion, extension, and radial and ulnar deviation. The grip strength was 
measured with a dynamometer. Postoperatively, clinical, and functional results were reported according to the modified Mayo wrist scoring system.

The radiographic evaluation involves plain radiograph posteroanterior, scaphoid view and lateral views preoperatively and postoperatively. The scapholunate (SL) angle was measured. The presence of AVN was diagnosed using MRI.

All operations were carried out under general anesthesia, and under an image intensifier control. The patients were lying in supine position with supinated forearm. A pneumatic tourniquet was applied to minimize bleeding.

A classic anterior incision (Henry's incision) was given and the radioscaphocapitate ligament was splitted by incision and later is repaired. The site of the nonunion was exposed, and the fibrous material was curetted until normal bone was visible. The surface of the proximal fragment was carefully inspected for bleeding points. The bleeding points were seen even with the tourniquet inflated. Then, at the level of distal radius, the pronator quadratus was identified, and a parallelepiped block of bone graft of 15$20 \mathrm{~mm}$ long was outlined at its distal insertion close to abductor pollicis longue tendon. Along the margin of the graft, holes were made with Kirschner- wire to facilitate separation with a fine osteotome. The pronator quadratus was not detached from the bone graft, and the muscle was dissected towards the ulna to secure a pedicle $20 \mathrm{~mm}$ thick. The proximal and distal segments of the scaphoid were aligned as a traction force was applied to the thumb. This maneuver allowed the bone graft to be inserted firm, into the space between the two fragments. The scaphoid with the bone graft inserted was firmly fixed with a Herbert-screw or with two $1.2 \mathrm{~mm}$ Kirschner- wires introduced at the scaphoid tuberosity. Screw fixation was preferred, but occasionally Kirschner wires were used if the bone fragments were too small. The skin incision was closed without tension, and a short arm slap was applied.

Patients were instructed for movement of fingers. Thumb motor and sensory examinations were done to evaluate neurovascularity.

In the postoperative follow-up, $14-21$ days after surgery, the sutures were removed and patients were immobilized in a short arm cast including the wrist and thumb for 4 - 10 weeks, and all Kirschner wires were removed within 8 - 10 weeks of operation. The patients were encouraged to do physiotherapy to improve the mobility and regain strength. Nonunions were considered healed after radiographic evidence of bone consolidation (bridge trabeculae on both sides of the graft, with attenuation of the continuity solution lines in the scaphoid.

Range of motion (flexion, extension, and radial and ulnar inclination), force and pain are measured preoperatively and at last follow-up. Consolidation time was determined using control X-rays. Complications, return to work, functional recovery on the Mayo Wrist Score and overall patient satisfaction were observed.

\section{Statistical methods:}

All data were collected, tabulated, and subjected to statistical analysis. Statistical analysis was performed by SPSS in general (version 20). Microsoft office 
Excel was used for data handling and graphical presentation.

Quantitative variables were described by the Mean, Standard Deviation, and the Range (Maximum - Minimum). Independent samples t-test was used for comparing means of the two groups.

Qualitative categorical variables are described by numbers and percentages.
Fisher exact test was applied to assess association.

Significance level was considered when $\mathrm{P} \leq 0.05$. Two tailed tests were assumed throughout the analysis for all statistical tests.

\section{RESULTS}

The average operative time was $90 \mathrm{~min}$ (range: $70-110 \mathrm{~min}$ ). The results were evaluated according to the fracture union, functional results, and complications.

In our study we used the pronator quadratus muscle pedicled bone graft for 10 patients, aging from 17 years old to 54 years old (the mean is 32.5 years). According to sex distribution, there were 7 males $(70 \%)$ and 3 females (30\%). According to side distribution, the injuries were in the right side in 6 patients $(60 \%)$, were in the left side in 4 patients $(40 \%)$. According to site distribution, the nonunion was in the proximal pole in 4 patients $(40 \%)$, was in the waist in 6 patients $(60 \%)$. According to Mode of trauma distribution, it was due to fall on the outstretched hand in 5 patients (50\%), RTA in 3 patients (30\%), direct blow trauma in 1 patient $(10 \%)$ and fall from hight in 1 patient (10\%). According to Herbert classification: The fracture was type $\mathrm{C}$ in 6 patients $(60 \%)$ and was type D1 in 4 patients $(40 \%)$. According to presence of pre-operative avascular necrosis, there were 6 patients not developed AVN $(60 \%)$ and 4 patients developed AVN (40\%). According to intraoperative tool of fixation of the fracture and the graft, we used k-wires in 6 patients $(60 \%)$, and used Herbert screw in 4 patients $(40 \%)$. According to the duration of preoperative nonunion it was ranging from 3 months to 11 months (mean 4.9 months) (Table 1). 
Table (1): Demographic data of studied cases

\begin{tabular}{|c|c|c|c|c|c|c|c|c|c|c|}
\hline Parameter & Case 1 & Case 2 & Case 3 & Case 4 & Case 5 & Case 6 & Case 7 & Case 8 & Case 9 & Case 10 \\
\hline AGE & 47 & 23 & 29 & 32 & 19 & 54 & 41 & 25 & 17 & 38 \\
\hline Sex & M & M & $F$ & M & M & M & $F$ & M & F & M \\
\hline Comorbidity & D.M & No & No & B.A,D.M & No & H.T.N, D.M & No & No & Epilapsy & $N_{0}$ \\
\hline $\begin{array}{l}\text { Mode of } \\
\text { trauma }\end{array}$ & $\begin{array}{c}\text { Fall on } \\
\text { outstratched } \\
\text { hand }\end{array}$ & $\begin{array}{c}\text { Fall on } \\
\text { outstratched } \\
\text { hand }\end{array}$ & R.T.A & $\begin{array}{c}\text { Fall on } \\
\text { outstretched } \\
\text { hand }\end{array}$ & Direct blow & $\begin{array}{c}\text { Fall on } \\
\text { outstratched } \\
\text { hand } \\
\end{array}$ & $\begin{array}{c}\text { Fall on } \\
\text { outstratched } \\
\text { hand }\end{array}$ & R.T.A & $\begin{array}{l}\text { Fall from } \\
\text { height }\end{array}$ & R.T.A \\
\hline $\begin{array}{l}\text { Site of } \\
\text { fracture }\end{array}$ & $\begin{array}{l}\text { Lt. Proximal } \\
\text { pole }\end{array}$ & $\begin{array}{c}\text { Rt. Proximal } \\
\text { pole }\end{array}$ & $\begin{array}{l}\text { Lt. Proximal } \\
\text { pole }\end{array}$ & $\begin{array}{c}\text { Rt. Proximal } \\
\text { pole }\end{array}$ & Lt. waist & Rt. Waist & Rt. waist & Lt. waist & Rt. Waist & Lt. waist \\
\hline Classification & Type C & Type Dl & Type C & Type C & Type Dl & Type Dl & Type C & Type C & Type C & Type Dl \\
\hline $\begin{array}{l}\text { Initial } \\
\text { treatment }\end{array}$ & $\begin{array}{l}\text { B.E scaphoid } \\
\text { cast }\end{array}$ & Neglected & $\begin{array}{c}\text { B.E scaphoid } \\
\text { cast }\end{array}$ & Neglected & $\begin{array}{c}\text { B.E } \\
\text { scaphoid } \\
\text { cast }\end{array}$ & $\begin{array}{c}\text { B.E scaphoid } \\
\text { cast then } \\
\text { neglected }\end{array}$ & $\begin{array}{c}\text { B.E scaphoid } \\
\text { cast }\end{array}$ & $\begin{array}{c}\text { A.E } \\
\text { scaphoid } \\
\text { cast for } 1.5 \\
\text { me, Then } \\
\text { below for } 2 \\
\text { mo. }\end{array}$ & Neglected & $\begin{array}{c}\text { B.E } \\
\text { scaphoid } \\
\text { cast then } \\
\text { neglected }\end{array}$ \\
\hline $\begin{array}{c}\text { Duration of } \\
\text { non-union }\end{array}$ & $3 \mathrm{mo}$. & $7 \mathrm{mo}$ & $4 \mathrm{mo}$. & $3.5 \mathrm{mo}$. & $3 \mathrm{mo}$. & $11 \mathrm{mo}$ & $3 \mathrm{mo}$. & $3.5 \mathrm{mo}$ & $5 \mathrm{mo}$. & $6 \mathrm{mo}$. \\
\hline AVN & No & AVN & AVN & No & No & AVN & No & No & No & AVN \\
\hline Operation & PQPBG & PQPBG & PQPBG & PQPBG & PQPBG & PQPBG & PQPBG & PQPBG & PQPBG & $\mathrm{PQPBG}$ \\
\hline $\begin{array}{l}\text { Tool of } \\
\text { fixation }\end{array}$ & $\mathrm{k}$-wires & $\mathrm{k}$-wires & $\mathrm{k}$-wires & $\mathrm{k}$-wires & $\begin{array}{l}\text { Herbert } \\
\text { screw }\end{array}$ & $\begin{array}{c}\text { Herbert } \\
\text { screw }\end{array}$ & K-wires & $\begin{array}{l}\text { Herbert } \\
\text { screw }\end{array}$ & $\begin{array}{l}\text { Herbert } \\
\text { screw }\end{array}$ & $\mathrm{K}$-wires \\
\hline $\begin{array}{c}\text { Post- } \\
\text { operative } \\
\text { complications }\end{array}$ & $\begin{array}{l}\text { Pin tract } \\
\text { infection }\end{array}$ & No & No & No & No & $\begin{array}{c}\text { sensory } \\
\text { disturbance } \\
\text { \$delayed } \\
\text { wound } \\
\text { healing } \\
\end{array}$ & No & No & No & No \\
\hline $\begin{array}{c}\text { Result after } 5 \\
\text { months of } \\
\text { follow up }\end{array}$ & Not united & Not united & Not united & united & united & united & united & united & united & united \\
\hline Mayo score & 55 (poor) & 65 (fair) & 45 (poor) & 75 (fair) & 85 (good) & 80 (good) & 85 (good) & $\begin{array}{c}90 \\
\text { (excellent) }\end{array}$ & $\begin{array}{c}95 \\
\text { (excellent) }\end{array}$ & 80 (good) \\
\hline
\end{tabular}

$M=$ male, $F=$ female, $B . A=$ bronchisl sthms, D.M $=$ diabotes mellitus, H.T.N $=$ hypertension, R.T.A $=$ rosd trafic accident, $B . E=$ below elbow, $A . E=$ sbove ellbow, P.Q.P.G $=$ pronator quadratus pediclad bone grat.

Increase of the flexion and extension angles means post-operative improvement. The wrist range of motion improved significantly. The mean preoperative wrist extension was $58.5^{\circ}$ (range $=55-65^{\circ}$ ) and improved to $72^{\circ}$ postoperatively $\left(\right.$ range $\left.=60-80^{\circ}\right)$. The mean preoperative flexion was $57.5^{\circ}$ (range $\left.=55-65^{\circ}\right)$ and improved to $71^{\circ}$ postoperatively $\left(\right.$ range $\left.=60-80^{\circ}\right)$. The hand grip strength also improved, with the average preoperative grip strength being $18.2 \mathrm{~kg}$ (range $=16-20 \mathrm{~kg}$ ) and the average postoperative grip strength being $26.2 \mathrm{~kg}$ (range $=22-30 \mathrm{~kg}$ ), (Table 2 and $3)$. 
Table (2): Results of the 10 patients with nonunion of fracture of the scaphoid

\begin{tabular}{|c|c|c|c|c|c|c|c|c|c|c|c|}
\hline Parameters & & Case 1 & Case 2 & $\begin{array}{c}\text { Case } \\
3 \\
\end{array}$ & $\begin{array}{c}\text { Case } \\
4 \\
\end{array}$ & Case 5 & $\begin{array}{c}\text { Case } \\
6 \\
\end{array}$ & Case 7 & Case 8 & Case 9 & Case 10 \\
\hline \multirow{2}{*}{ Pain } & $\begin{array}{c}\text { Pre- } \\
\text { operative }\end{array}$ & + & + & + & + & + & + & + & + & + & + \\
\hline & $\begin{array}{c}\text { post- } \\
\text { operative }\end{array}$ & $+/-$ & $+/-$ & + & - & - & + & - & - & - & - \\
\hline \multirow{2}{*}{$\begin{array}{l}\text { Flexion } \\
\text { (angle in } \\
\text { degree) }\end{array}$} & $\begin{array}{c}\text { Pre- } \\
\text { operative }\end{array}$ & 55 & 60 & 55 & 55 & 60 & 55 & 55 & 65 & 60 & 55 \\
\hline & $\begin{array}{c}\text { post- } \\
\text { operative }\end{array}$ & 60 & 65 & 60 & 75 & 80 & 60 & 75 & 80 & 80 & 75 \\
\hline \multirow{2}{*}{$\begin{array}{l}\text { Extension } \\
\text { (angle in } \\
\text { degree) }\end{array}$} & $\begin{array}{c}\text { Pre- } \\
\text { operative }\end{array}$ & 60 & 55 & 55 & 60 & 60 & 55 & 60 & 65 & 55 & 60 \\
\hline & $\begin{array}{c}\text { post- } \\
\text { operative }\end{array}$ & 65 & 60 & 65 & 75 & 80 & 65 & 75 & 80 & 80 & 75 \\
\hline \multirow{2}{*}{$\begin{array}{l}\text { Grip strength } \\
\text { (In Kg) }\end{array}$} & $\begin{array}{c}\text { Pre- } \\
\text { operative }\end{array}$ & 18 & 17 & 16 & 20 & 19 & 17 & 18 & 20 & 19 & 18 \\
\hline & $\begin{array}{c}\text { post- } \\
\text { operative }\end{array}$ & 24 & 25 & 23 & 26 & 28 & 22 & 28 & 29 & 30 & 27 \\
\hline $\begin{array}{c}\text { Time of union } \\
\text { (weeks) }\end{array}$ & & $\begin{array}{c}\text { Not } \\
\text { united }\end{array}$ & $\begin{array}{c}\text { Not } \\
\text { united }\end{array}$ & $\begin{array}{c}\text { Not } \\
\text { united }\end{array}$ & 16 & 14 & $\begin{array}{c}\text { Not } \\
\text { united }\end{array}$ & 15 & 12 & 10 & 12 \\
\hline $\begin{array}{c}\text { Clinical } \\
\text { results (Mayo } \\
\text { wrist score) }\end{array}$ & & $\begin{array}{c}55 \\
\text { poor }\end{array}$ & $\begin{array}{l}65 \\
\text { fair }\end{array}$ & $\begin{array}{c}45 \\
\text { poor }\end{array}$ & $\begin{array}{c}75 \\
\text { good }\end{array}$ & $\begin{array}{l}85 \\
\text { good }\end{array}$ & $\begin{array}{c}45 \\
\text { poor }\end{array}$ & $\begin{array}{c}85 \\
\text { good }\end{array}$ & $\begin{array}{c}90 \\
\text { Excellent }\end{array}$ & $\begin{array}{c}95 \\
\text { Excellent }\end{array}$ & $\begin{array}{c}80 \\
\text { good }\end{array}$ \\
\hline
\end{tabular}

Table (3): Change in mean values in flexion, extension, and grip strength

\begin{tabular}{|l|c|c|c|c|}
\hline Parameters Values & Minimum & Maximum & Mean & SD \\
\hline Flexion (in degree) & \multicolumn{5}{|l|}{} \\
\hline Flexion Pre & 55.00 & 65.00 & 57.50 & 3.54 \\
\hline Flexion Post & 60.00 & 80.00 & 71.00 & 8.76 \\
\hline $\begin{array}{l}\text { Flexion Difference } \\
\text { (Post - Pre) }\end{array}$ & 5.00 & 20.00 & 13.50 & 7.47 \\
\hline Extension (in degree) \\
\hline Extension Pre & 55.00 & 65.00 & 58.50 & 3.37 \\
\hline Extension Post & 60.00 & 80.00 & 72.00 & 7.53 \\
\hline $\begin{array}{l}\text { Extension Difference } \\
\text { (Post - Pre) }\end{array}$ & 5.00 & 25.00 & 13.50 & 6.26 \\
\hline Grip strength (in Kg) & 16.00 & 20.00 & 18.20 & 1.32 \\
\hline Grip strength Pre & 22.00 & 30.00 & 26.20 & 2.66 \\
\hline Grip strength Post & 5.00 & 11.00 & 8.00 & 1.94 \\
\hline $\begin{array}{l}\text { Grip strength } \\
\text { Difference (Post - Pre) }\end{array}$ & 5
\end{tabular}

The mean preoperative scapholunate and postoperatively it improved to $46.5^{\circ}$ angle angles were $61^{\circ}\left(\right.$ range $\left.=50-70^{\circ}\right) \quad\left(\right.$ range $\left.=40-50^{\circ}\right)($ Table 4 and 5)

Table (4): Preoperative and postoperative assessment of the scapholunate angle

\begin{tabular}{|l|c|c|c|c|c|c|c|c|c|c|}
\hline Cases & Case & Case & Case & Case & Case & Case & Case & Case & Case & $\begin{array}{c}\text { Case } \\
\mathbf{1}\end{array}$ \\
\hline $\begin{array}{l}\text { Preoperative } \\
\text { SL angle }\end{array}$ & 55 & 60 & 60 & 55 & 70 & 65 & 65 & 60 & 70 & 50 \\
\hline $\begin{array}{l}\text { Postoperative } \\
\text { SL angle }\end{array}$ & 50 & 45 & 45 & 50 & 45 & 45 & 50 & 45 & 40 & 50 \\
\hline
\end{tabular}


Table (5): Change in mean values in scapho-lunate angle

\begin{tabular}{|c|c|c|c|c|}
\hline $\begin{array}{ll}\text { Parameters } & \text { Values } \\
\end{array}$ & Minimum & Maximum & Mean & SD \\
\hline Scapho-lunate angle Pre & 50.00 & 70.00 & 61.00 & 6.58 \\
\hline Scapho-lunate angle Post & 40.00 & 50.00 & 46.50 & 3.37 \\
\hline Scapho-lunate angle Difference (Post - Pre) & -30.00 & 0.00 & -14.50 & 9.26 \\
\hline
\end{tabular}

The overall union rate after 5 months was $70 \%$ ( 7 patients). The time of union for only 7 united cases ranged from 10 weeks to 16 weeks (mean 13.57). Functional results according to wrist mayo scoring system, ranged from 45 to 95 (mean 75.5), 2 patients had poor score (20\%), 2 patients had fair score $(20 \%), 4$ patients had good score $(40 \%)$, and 2 patients had excellent score (20\%) (Tables 6, 7, and 8).

Table (6): Result after 5 months of follow up

\begin{tabular}{|c|c|c|}
\hline & Frequency & Percent \\
\hline Not united & 3 & $30 \%$ \\
\hline United & 7 & $70 \%$ \\
\hline
\end{tabular}

Table (7): Time of union after the operation for only the 7 cases united (in weeks)

\begin{tabular}{|c|c|c|c|}
\hline Minimum & Maximum & Mean & SD \\
\hline 10.00 & 16.00 & 13.57 & 2.30 \\
\hline
\end{tabular}

Table (8): Mayo score

\begin{tabular}{|c|c|c|c|}
\hline Minimum & Maximum & Mean & SD \\
\hline 45.00 & 95.00 & 75.50 & 15.89 \\
\hline
\end{tabular}

According to the relation of results after 5 months of follow up and site of fracture, 3 of cases who suffered proximal pole nonunion were not united and all cases who suffered waist nonunion were united. (Fisher exact $\mathrm{p}$ value 0.0333) (P $<0.05$ significant). The association between results after 5 months of follow up and site of nonunion is considered to statistically significant (Table 9).

Table (10): Relation between results and site of fracture

\begin{tabular}{|c|c|c|c|}
\hline Result & $\begin{array}{c}\text { Proximal pole } \\
\text { nonunion }\end{array}$ & $\begin{array}{c}\text { Waist } \\
\text { nonunion }\end{array}$ & $\begin{array}{c}\text { Fisher Exact test } \\
\text { P Value }\end{array}$ \\
\hline Not united & 3 & 0 & 0.0333 \\
\hline United & 1 & 6 & \\
\hline
\end{tabular}

\section{DISCUSSION}

Scaphoid nonunion is a challenging and complex problem which results owing to multiple factors. Over the last years, different methods for scaphoid nonunion reconstruction have been described. Because of the frequency of the disease, a successful method for daily operative practice is necessary. 
In our study, we used the pronator quadratus muscle pedicled bone graft for 10 patients suffering from delayed union and nonunion of proximal pole and waist scaphoid fracture. The main advantage of this procedure was that it respects the normal principles of fracture-healing. The volar approach provides an excellent access to the volar part of the cortex of the scaphoid which can be easily reconstituted with a vascularized bone graft from distal radius and internally fixated with an implant (Herbert screw or Kirschner wires).

We achieved complete union and satisfactory functional results in 7 patients from all the 10 patients. When we compared the results according to site of nonunion, we found that the results were statistically significantly higher in waist fractures compared to proximal pole fractures, as we achieved a complete union in 6 patients suffering from waist non united scaphoid fracture (union rate $100 \%$ ) and just 1 patient of 4 patients suffering from non-united proximal pole scaphoid fracture (union rate 25\%). According to Mayo score system of the wrist function, we achieved excellent and good results in 6 patients with waist scaphoid non unions, fair results in 2 patients with proximal pole scaphoid nonunion and poor results in 2 patients with proximal pole scaphoid nonunion.

Gras and Mathoulin (2011) reported a retrospective study included 111 cases of vascularized bone graft for scaphoid nonunion as primary procedure in 73 cases and secondarily in 38 . This study concluded that primary treatment by vascularized graft depending on the series showed equally good or better consolidation, recovery of motion and pain relief compared to secondary treatment or non-vascularized graft. Vascularized graft from the volar radius is thus a good alternative for primary treatment of scaphoid non-union.

Mathoulin and Gras (2015) reported a case presentation of a 42 years old male patient; he decided to use a vascularized bone graft utilizing a volar pedicled graft based off the volar carpal artery. The union was achieved in 6 weeks. He concluded that vascularized bone grafts seem to be a good option for primary treatment of scaphoid nonunion because the union rate is very high.

Obada et al. (2015) reported on a volar pronator quadratus pedicled bone graft for six patients suffering from non-united waist scaphoid fracture, they achieved union in all six patients, with time range of union $8-12$ weeks, with functional results varying from good to excellent according to mayo wrist score.

Goel et al. (2017) reported a study that was done on eleven cases of nonunion scaphoid with pronator quadratus vascularized bone graft. Postoperative scaphoid outcome score was excellent in 4 cases, good in 4 cases, fair in 2 cases, and poor in 1 case. One case developed scaphoid nonunion advanced collapse and wrist arthritis.

\section{CONCLUSION}

We recommend the use of this approach in the delayed or non-united waist scaphoid fracture as it provided an excellent access to the volar part of the cortex of the scaphoid which can be easily reconstituted with a vascularized bone graft from distal radius and stable fixated 
with an implant (Herbert screw or Kirschner wires), in addition to its satisfactory results to the patient.

\section{REFERENCES}

1. Goel, V., Valecha, N., Bhuyan, B. K., Sharma, S. K. and Singh, V. (2017): Nonunion scaphoid treated with vascularized pronator quadratus osteomuscular transposition flap: a review of 11 cases. Journal of Orthopedics, Traumatology and Rehabilitation, 9(2): 106-112.

2. Gras, M. and Mathoulin, C. (2011): Vascularized bone graft pedicled on the volar carpal artery from the volar distal radius as primary procedure for scaphoid non-union. Orthopaedics \& Traumatology: Surgery \& Research, 97(8): 800-806.

3. Lee, S. K., Park, J. S. and Choy, W. S. (2015): Scaphoid fracture nonunion treated with pronator quadratus pedicled vascularized bone graft and headless compression screw. Annals of plastic surgery, 74(6): 665-671.

4. Mathoulin, C. and Gras, M. (2015): Scaphoid Nonunion: Surgical Fixation with Vascularized Bone Grafts-Volar Pedicle. In: Scaphoid Fractures and Nonunions. Pbl Springer, Cham, 176-167.

5. Nassiri, M., Mohamed, O., Berzins, A., Aljabi, Y., Mahmood, T., Chenouri, S. and O'Grady, P. (2016): Surfing behind a boat: quality and reliability of online resources on scaphoid fractures. The Journal of Hand Surgery (Asian-Pacific), 21(03): 374-381.

6. Obada, B., Serban, R. O., Badauta, M., Obada, A. T, and Costea, D. (2015): Treatment of nonunion of the scaphoid with pronator quadratus pedicled bone graft. Journal of Orthopaedics Trauma Surgery and Related Research, 10(1): 22-30.

7. Rashed, R. E. (2015): The use of pedicled vascularized bone graft from the dorsum of distal radius for the treatment of scaphoid nonunion. The Egyptian Orthopaedic Journal, 50(3): 187.-194.

8. Werdin, F., Jaminet, P., Naegele, B., Pfau, M. and Schaller, H. E. (2014): Reconstruction of scaphoid nonunion fractures of the proximal one third with a vascularized bone graft from the distal radius. Eplasty, 14(6): 164-173.

9. Wong, K. and von Schroeder, H. P. (2011): Delays and poor management of scaphoid fractures: factors contributing to nonunion. The Journal of hand surgery, 36(9): 14711474.

10. Yin, Z. G., Zhang, J. B., Kan, S. L. and Wang, X. G. (2010): Diagnosing suspected scaphoid fractures: a systematic review and meta-analysis. Clinical Orthopaedics and Related Research, 468(3): 723-734. 


\section{إستخدام الرقعة العظمية المستخلصة من أسفل عظمة الكعبرة

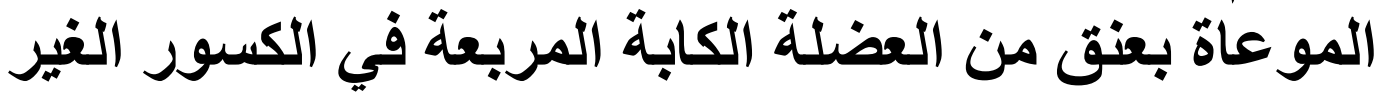 ملتئمة بالعظمة الزورة الزية المرية فية}

خالد أحمد أبو الفضل، إبراهيم أحمد حسين، فيصل حسن زايد قسم جراحة العظام، كلية الطب، جامعة الأزهر

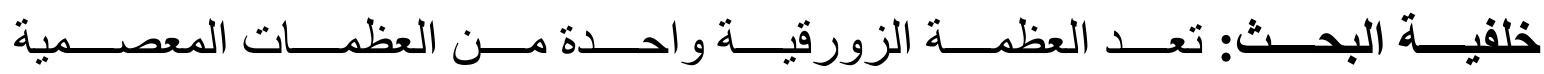

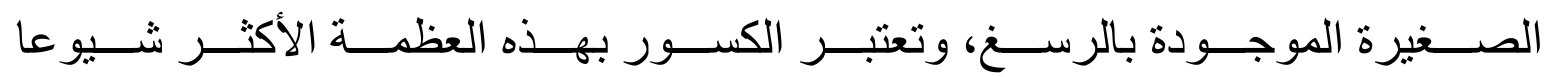

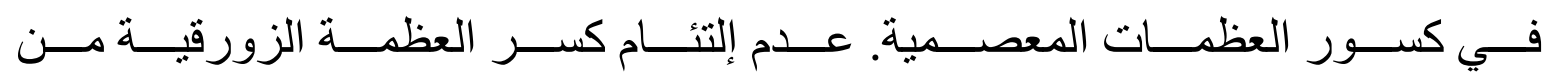

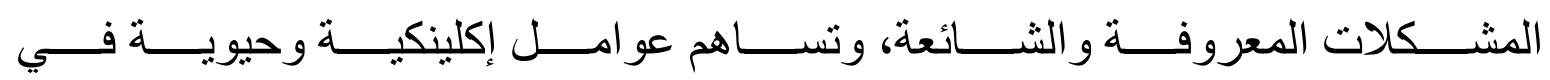

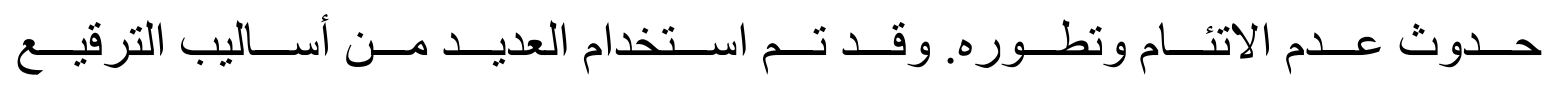

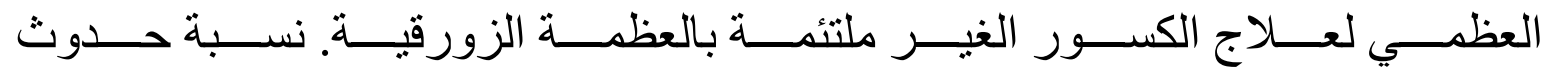

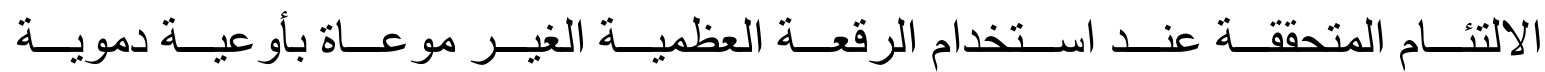

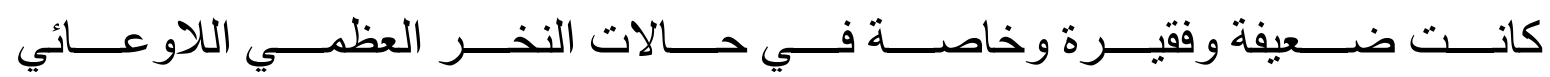

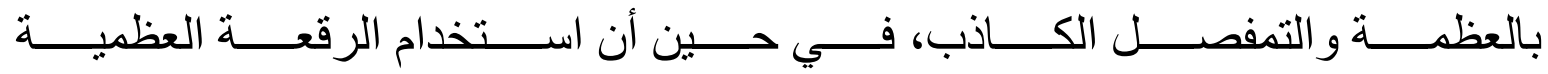

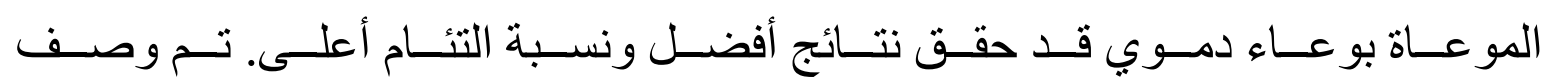

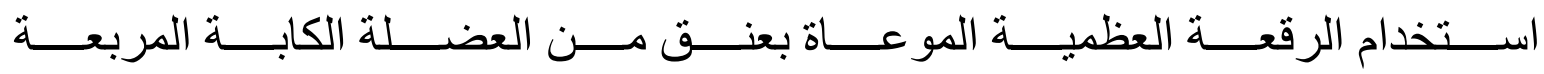
كوسيلة ناجحة لعلاج الكسور الغير ملتئية بالعظمة الزورقية.

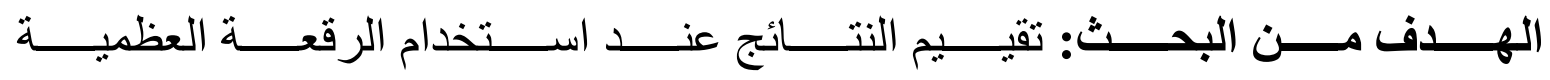

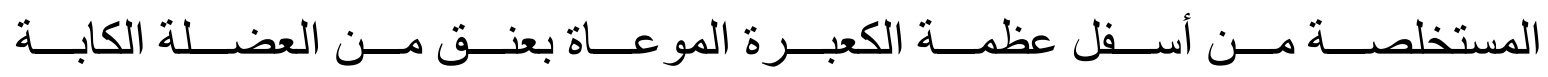

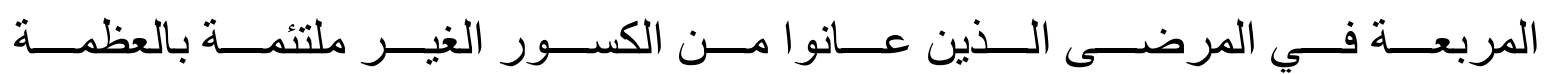

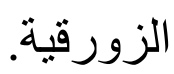

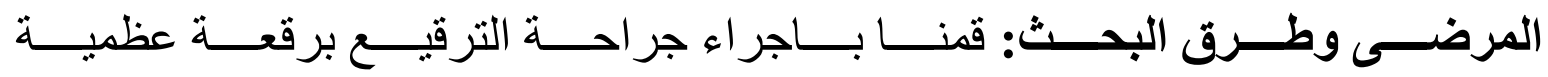

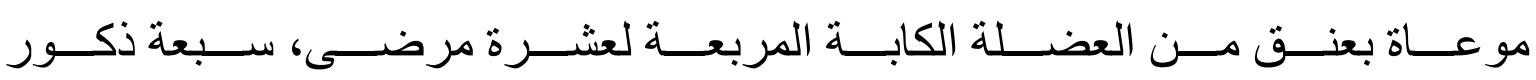
وثناث إناث، تتر اوح أعمار هم بين السابعة عشر و الر ابعة والخمسون. 


\section{PRONATOR QUADRATUS MUSCLE PEDICLED BONE GRAFT...}

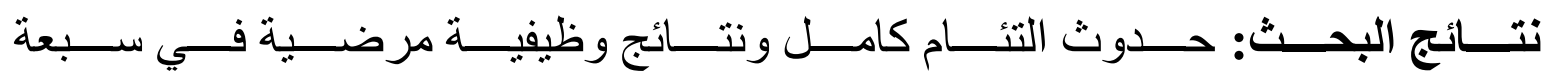

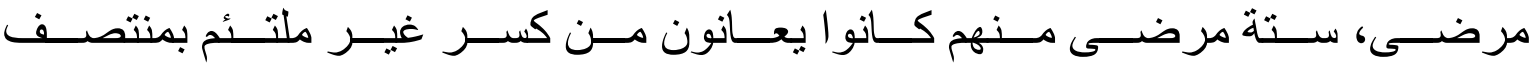

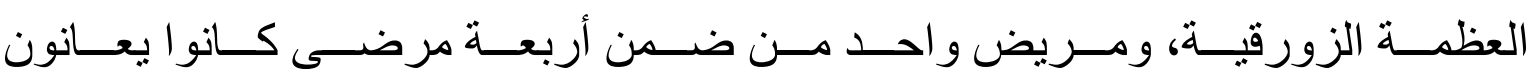
من كسر غير ملتئم بالقطب البعيد من العظمة الزورقية.

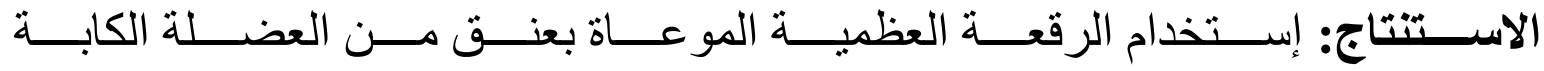

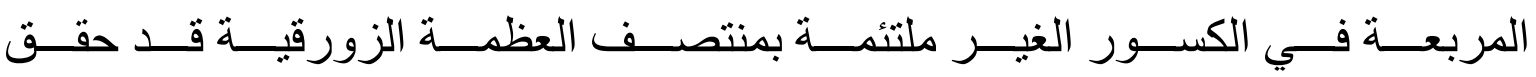

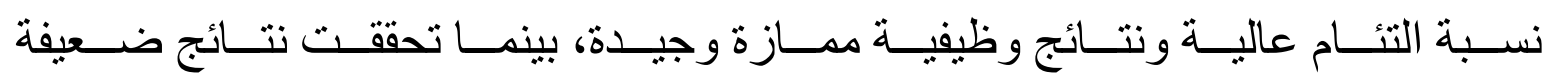

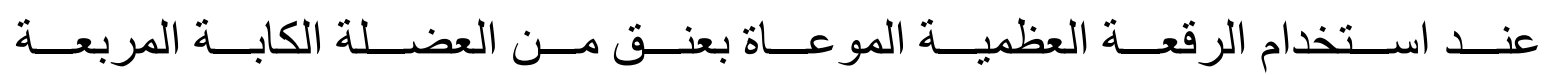
في الكسور الغير ملتئمة بالقطب البعيد بالعظمة الزورقية. 